\title{
The Effect of Increasing Student Involvement with Career Development Services: The Integration of Faculty Members \& Fostering Student/Faculty Relationships
}

\section{Luke Easton Wurban, Wesley Amundson, Albert Ho Si, Morgan Bosgoed, \& Antonio Makardajh}

\begin{abstract}
The primary goal of this research is to recognize and disseminate the possible components of what makes students more involved with career development services on campus. We examined 25 scholarly articles as part of our initial research to identify possible relationships, which led us to one major question to answer: "How can we increase the student usage of the MacEwan University Career Development and Experiential learning office by integrating faculty members of various departments?" Some of the largest problems that we found when speaking with the Career Development services and professors are that both students and faculty are unaware of what Career Development Services is, and what services they provide.

Our qualitative research with faculty members indicated that they do not know of the availability of career development services on campus, and that faculty does not communicate with the office very frequently. This research allowed us to formulate a well-rounded quantitative survey to be administered to other faculty members that reflects possible solutions to create more student involvement, and by extension, more student success. Our sample data included 28 responses of our possible 361 survey questionnaires sent. We did not have the greatest response rate; therefore, our findings are not fully generalizable. However, the responses that we did receive are very important and informative to the Career Development Services of MacEwan University, which helps aid in conclusions and recommendations for student involvement.
\end{abstract}

\section{Problem Definition}

Our client for this project is the Career and Experiential Learning office (CDEL) at MacEwan University. CDEL helps students and alumni career plan, search for jobs, prepare for interviews, get advice on placements, learn about graduate school, review resume/cover letters and more. CDEL has developed a module called "My Career Journey", which they would like to see have an increased number of students engaging in the module.

For us as a group to gain more knowledge on career centers at universities, we created a literature review. The scholarly articles we studied gave us a good foundation to develop a questionnaire for our in-depth interviews, as we learned what career centres all over North America struggle with. Before the in-depth interviews, we sat down with Kellie Fay and Gillian Kemp from the CDEL to learn more about the "My Career Journey" module. After developing our questionnaire for in-depth interviews, we met with five faculty members from MacEwan 


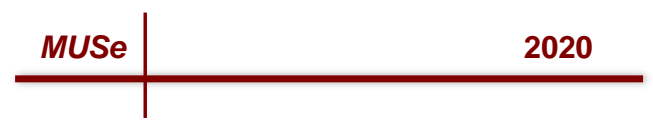

University to determine if they had any prior knowledge of the career development program that MacEwan offers, and what would be required to motivate them and other faculty members to participate in using and teaching this program. With our in-depth interviews completed, we gained a better understanding of faculty member's knowledge of the module and what it would take for them to use it.

After scrutinizing the results from the five in-depth interviews, we were able to focus more on the issues and develop questions for our survey. Having a more specific type of "My Career Journey" module for each faculty, while giving students some sort of intrinsic value to complete it, would go a long way in attracting more students to complete the module. Through this part of the research, it will give CDEL a better idea of what would attract faculty to implement this module as part of a class and encourage students to use it.

\section{Analytical Framework}

\section{Literature Review \& Exploratory Research}

After a lengthy and thorough analysis and synthesis of scholarly articles, we could conduct indepth interviews with our recommended target market of MacEwan faculty members. Our initial literature review process pointed us in a few different directions regarding research, which expanded to concepts such as: barriers to accessing career services, where and how students are currently seeking employment, what is currently successful for the CDEL office, effectiveness of "how-to" videos, and fostering student and faculty interactions. From the articles we compiled, the main focus revolved around generating student engagement toward the programs and services that the CDEL office has available. Upon informing our client of the data that we had collected, they re-formed our focus to narrow our qualitative analysis to topics that outline the effectiveness of faculty involvement toward the CDEL office. After the initial data collection was completed, alongside the conversations with the CDEL representatives, our problem definition was apparent: "How can we increase the student usage of the MacEwan University Career Development and Experiential learning office by integrating faculty members of various departments?"

The most crucial topic that we elaborated on was the fostering of faculty involvement toward the CDEL office to improve student engagement that would ensure the future success of graduates. Student engagement with their program and faculty (professors and career planning) is crucial to ensure student achievement. As described the Children and Youth Services Review, social bonds in college are related to college and professional success; as students transition to early adulthood, "connections with professions in and beyond their social networks can take on increased significance, providing vital information and resources that can enhance academic and career opportunities" (Schwartz et. al, 2016). This distinction creates a parallel to an integrated program between faculty and students on the career journey, which possesses value that may increase student and faculty involvement. This process was very beneficial and helped create valuable discussion questions related to faculty's opinions on the benefits of module based programs, which allows us to recommend reform on what is currently beneficial for the existing "My Career Journey", and what could be added/amended. 


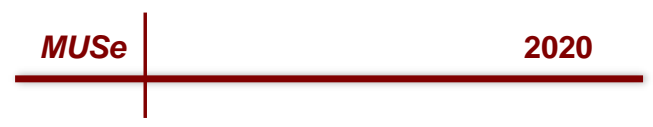

Another relevant topic that we researched was the relationship between "how-to videos" and student engagement/satisfaction. A study conducted in the Zhong academic study indicated that students who used instructor-made video tutorials had higher course satisfaction and evaluation. In addition, tutorial videos were found to be integral for lower performing students, as they found the videos to be more helpful for course material (Zhong, 2017). Although the study was directed at student engagement, the CDEL office explained that faculty engagement, as well as knowledge regarding the program, is also an issue. As a result, the use of "how-to videos" and templates (for resumes/CV's) could be beneficial to both students and faculty members by demonstrating how to locate and operate the program effectively. While it would be advantageous for faculty members to have existing knowledge about the "My Career Journey" module, for those who are unaware, simple "how-to" videos and informative templates would be an effective way to introduce it to them. Therefore, we found it essential to include in our questionnaire and in-depth interviews the level of knowledge and agreeance to these factors that the interviewees had prior to this study.

\section{Research Questions}

Our creation and dissemination of research was based on the following components that consist of the major topics that we considered to be relevant to the CDEL office. After the initial qualitative analysis of literature review, our meeting with the CDEL office representatives, and in-depth interviews of experts (MacEwan faculty), the information we gained allowed us to create polished questions that would provide answers to the major topics of research relevant to the CDEL office. Our initial findings of secondary research were not entirely transferrable to the questions that we had created, due to the switch in focus of our target market, therefore many of these questions are only supported by a portion of our literature review.

Research Question \#1: How aware is MacEwan faculty to what the CDEL office is, and what sort of services that they have available?

Hypothesis: Our initial research of in-depth interviews allowed us to surmise that many faculty members of MacEwan do not know what the CDEL office is, and by extension do not know what services they offer to students. As a result, these questions and findings may allow us to recommend what sort of marketing efforts needed for faculty members to refer students to the CDEL office in the future.

Research Question \#2: How much communication and coordination does the CDEL office have with MacEwan faculty?

Hypothesis: As an extension from our first research question, we found that because many faculty members are unaware of the services that are available, they may not communicate or coordinate with the CDEL offices often, or at all. This question allows us to gauge how much existing coordination there is between faculty and the CDEL office, which will allow us to recommend alternatives to both parties for the benefit of students. 


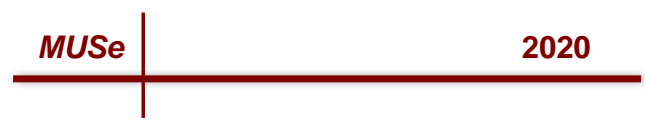

Research Question \#3: What is the faculty opinion on the importance of the CDEL office, including what services they offer?

Hypothesis: We understood that, after collecting expert opinions from many educated professionals at MacEwan University, the services that are currently available from the CDEL office can be critiqued in an unbiased way. By describing what faculty feels is important and unimportant (on a likert scale), it will provide us with an anchored hypothesis and understand what may be currently vital for students, and what could be removed/amended.

Research Question \#4: How confident are MacEwan faculty members regarding employment for students after graduation of their program?

Hypothesis: From our in-depth interviews, it is apparent that students often come to MacEwan faculty members for help with reference letters, interview advice, job placement help, resume reviews, etc. As a result, this question describes what sort of existing services and placements that students may have available (in their mind) that would help their odds in gaining employment after graduating from their program. The answers collected may describe a "gap" between course work and the labor market that we hope to fill through integration of the CDEL office with faculty members.

Research Question \#5: What is the faculty opinion on the role that they have for preparing students for the labor market after graduation?

Hypothesis: Our initial research described that the benefits of faculty involvement for development of students cannot be overlooked; relationships and mentorship of individuals has an extremely positive correlation to test marks and class attendance/retention. As a result, we were curious as to what sort of impression that faculty believes they have for students and the labour market post-graduation. This question allows us to learn what sort of ideas faculty has regarding their role in students' employment post-graduation, which will allow us to determine how willing faculty would be to cooperate with the CDEL office in the future.

Research Question \#6: What is the faculty opinion on potential services that the CDEL office could implement to increase the usage of their modules for students?

Hypothesis: Referring to a mixture of the previous research questions, this inquiry takes into account the existing "My Career Journey" module that the CDEL office has available for students, and offers faculty members with a list of (potential) integrations that the CDEL office could add to the module to make it more effective. Based on a scale of level of importance, the answers provided by faculty members documents an exclusive point of view that can provide the CDEL office with implementation options to help with student involvement and employment success post-graduation. 


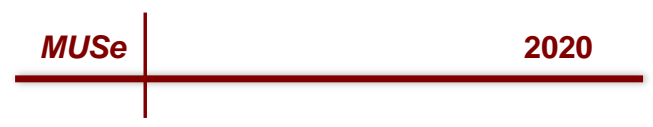

Research Question \#7: What is the faculty opinion regarding the importance of their involvement with the CDEL office to increase student involvement?

Hypothesis: After conducting a large amount of research about the importance of fostering student and faculty relationships during the course of an academic career, we were curious as to what faculty opinions were regarding these relationships. If they personally found fostering relationships important, it may be a good indicator that there should be more communication between the CDEL office and faculty members. This question allows us to interpret the understanding of faculty regarding their own personal importance in the future success of students.

Research question \#8: Which of the available service would you consider most important for your student's future success?

Hypothesis: We made this question in hopes to obtain a better understanding of faculty's opinion regarding the importance of services the CDEL offers. This is useful feedback for our client to review when deciding what future services they may choose to provide. It also indicates what services appeal most to professors in regards to student success.

\section{Research Design: Descriptive Design}

When planning our research design for the CDEL office, initially our group wanted to conduct a probability technique using random sample from all elements within our target. This included associate professors, full professors, sessional professors, administration, lab technicians, and assistants with various titles from all departments. After reviewing our objective, we concluded that positions such as administration, assistants, and lab technicians had little relevance in determining course content. This lowered our population size dramatically. Therefore, our method of gathering these respondents was by using non-probability techniques of judgmental and convenience sampling. Our reasoning behind this method was to collect data at our own convenience while obtaining high response rates. We collected 28 valid faculty responses from various departments at MacEwan University. The demographics are in the table below.

\section{Field-work Data Collection}

Through our initial report, our group had previously gathered secondary information and corresponding themes that were re-occurring in the academic journals collected. Through these journals we were able to create a base for our main concerns with the Career Development and Experiential Learning office at MacEwan University. As a group, we were able to focus in on the qualitative data presented that outlined problems that the marketing research would address. By carefully studying our findings, our team decided to proceed to the next step which included five in-depth interviews with faculty members regarding their experiences with/or current knowledge of MacEwan Career Development and Experiential Learning. These in-depth interviews were requested via email and organized to fulfill the request of each faculty member that chose to participate. This was to ensure each interviewee was comfortable with meeting with us and to ensure our interviews went smoothly to the best of our ability. Through this exploratory research 


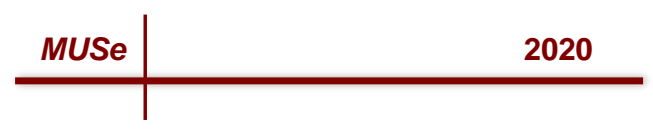

design, our main goal was to acquire new information that would help increase awareness and usage of the services provided by CDEL.

After completing these five in-depth interviews with professors from the Arts \& Sciences Faculty as requested by the CDEL, our group gained a better understanding of the perspective each faculty member had about the current issues regarding faculty at MacEwan, allowing all sides of stakeholders to be heard with their expert opinions and suggestions being documented. While reviewing our interviews, it was evident that opinions varied from participants as some coincided with each other, while others were drastically different. This provided a great insight as to the underlying flaws of the Career Development Office and how taking certain steps can better improve the current system to make it beneficial for all members involved. In doing so, we used projective probing techniques to gain these answers for the Career Development office.

\section{Development, Pre-testing, and Execution of the Questionnaire}

As a group, through our marketing research for the Career Development and Experiential Learning Offices, we gathered information using qualitative and exploratory data sets, including literature reviews, analyzing academic journals, the five in-depth interviews conducted with members of the Arts and Sciences faculty, and extensive research on topics regarding how to expand the usage of the Career Development office at MacEwan University by integrating faculty members of various departments to gather information. With faculty members being our target demographic, our questions and resources were primarily focused on examining their insights and knowledge of the CDEL offices. We proceeded to carefully construct a questionnaire survey made specifically to target faculty members of MacEwan University using our previous understanding based off our in-depth interviews and prior research. Prior to the distribution of our questionnaire we had our drafted copy peer-reviewed by colleagues in our class with the supervision of Dr. Fernando Angulo-Ruiz. With the feedback we were able to create a better final draft.

The next step was to make sure that our final draft of the questionnaire was given approval from our clients. By sending a draft to the CDEL offices we were able to use their suggestions to better develop more insight from the questions being asked. Our survey consisted of various types of questions which assured a well-balanced format seeing dichotomous questions, multiple choice questions, scales and other methods of formatting. As a group we decided that the most effective way of distributing our questionnaire was through the use of email, which saw each member of our group tackle different faculties with a rough estimate of about three hundred emails being sent. Ultimately, we believed that this method would have given us the best results in terms of participation among faculty doing our questionnaire, however only 28 of our desired target demographic responded.

\section{Ethical Issues}

In order for our group to gather our quantitative data, we first had to determine which survey method would be most practical to our research problem. We determined that the use of online surveys with multiple responses would be the most beneficial method in collecting data for the 


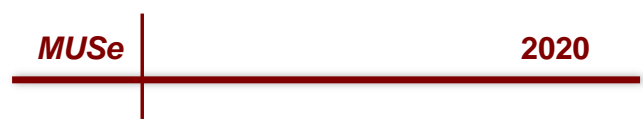

purpose of our research objective: to combine the faculty perspective and mindset to assist in increasing student engagement. We used a database that contained faulty members contact information from all departments at MacEwan. As a group we then divided up different departments for each of us to target. We sent out electronic e-mails during a seven-day period to 340 faculty members. The email we sent introduced our group and explained the merits of our objective. The e-mail contained a link that took participants to our google form survey where we would collect their responses. To follow ethical procedures we provided a consent form to participants regarding their involvement in the study through the Google Form template. This provided them our approval on ethical grounds by the MacEwan University Research Ethics Board on [October 2, 2015].

However, due to the consent being visible only through the link, some faculty members were skeptical. Our group received an email back from the chair of the department of psychology who informed us that, though she was certain of the legitimacy of our research, many of her colleagues in the department expressed their concern that our email could be associated with a phishing scheme. At this time, our group sent out a second email to all members of the department under study to clarify any concerns. We included the contact information of our supervisor, as well as our client from the CDEL office, who could verify our involvement in this study. Though we followed all ethical procedures, our group did not account for misinterpretations regarding our initial emails. This was the only ethical issue our group faced when collecting our quantitative data.

Table 1.1 Faculty Respondents Demographic

\begin{tabular}{|l|c|c|}
\hline \multicolumn{1}{|c|}{ Demographics } & Number of Respondents & $\%$ of Respondents \\
\hline What faculty are you a part of? & & \\
& & \\
Arts \& Sciences & 10 & $35.7 \%$ \\
Health \& Community Studies & 3 & $10.7 \%$ \\
Nursing & 4 & $14.3 \%$ \\
School of Business & 11 & $39.3 \%$ \\
& & \\
& & \\
& & \\
What is your current position? & & \\
Assistant Professor & 12 & $32.9 \%$ \\
Associate Professor & 9 & $3.6 \%$ \\
Full Professor & 1 & $3.6 \%$ \\
Other & 1 & $17.9 \%$ \\
$\quad$ Sessional Instructor & 5 & \\
\hline$\quad$ Total & $\mathbf{2 8}$ & \\
\hline
\end{tabular}




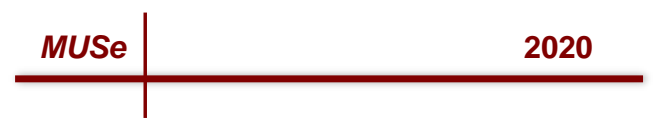

\section{Data Analysis and Results}

Research Question \#1: How aware are MacEwan faculty about what the CDEL office is and what sort of services that they have available?

Table 2: Knowledge of CDEL Office and the Services Available

(Sample mean $=1.36, S D=0.488$ )

\begin{tabular}{ll|r|r|} 
& & Frequency & Percent \\
\hline Valid & No & 18 & 64.3 \\
\cline { 2 - 3 } & Yes & 10 & 35.7 \\
\cline { 2 - 3 } & Total & 28 & 100.0 \\
\hline
\end{tabular}

Table 2 shows an interesting result that only $64 \%$ of all faculty members in our sample size had knowledge of the CDEL office and their services that are available; these findings mirror our initial in depth interviews that many of our interviewees had little to no knowledge of the CDEL office.

Research Question \#2: How much communication and coordination does the CDEL office have with MacEwan faculty?

Table 3: How Often per year MacEwan Faculty Members Communicate with the CDEL Office (1=never, $7=$ very often) (Sample mean $=1.71, S D=1.41$ )

\begin{tabular}{|c|c|c|c|}
\hline & & Frequency & Percent \\
\hline \multirow[t]{8}{*}{ Valid } & 1 & 20 & 71.4 \\
\hline & 2 & 3 & 10.7 \\
\hline & 3 & 2 & 7.1 \\
\hline & 4 & 0 & 0.0 \\
\hline & 5 & 2 & 7.1 \\
\hline & 6 & 1 & 3.6 \\
\hline & 7 & 0 & 0.0 \\
\hline & Total & 28 & 100.0 \\
\hline
\end{tabular}

Table 3 shows a more in-depth answer to Table 2, proving that of our 28 respondents, only 3 had contact relatively often with the CDEL office, equating to roughly $11 \%$ of all respondents. The remaining $89 \%$ of respondents never had contact with the CDEL office, or if they did, it was not very often. It is notable that $71 \%$ of all the respondents have never communicated with the CDEL at all.

Research Question \#3: What is the faculty opinion on the importance of the CDEL office, including what services they offer? 


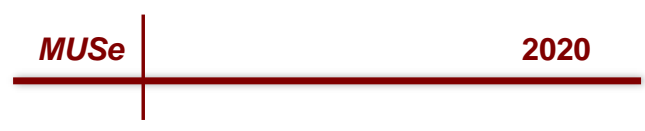

Table 4: Level of Satisfaction Regarding the Existing Services that the CDEL Office has Available (Sample mean $=1.39, S D=0.994$ )

\begin{tabular}{ll|r|r|} 
& Frequency & Percent \\
\hline Valid & 1 & 3.6 \\
\cline { 2 - 4 } & Unery Unsatisfied (1) & 1 & 3.6 \\
\cline { 2 - 4 } & Neutral (No Opinion/Unsure) (3) & 23 & 82.1 \\
& & \\
\hline Satisfied (4) & 2 & 7.1 \\
\hline Very Satisfied (5) & 1 & 3.6 \\
\hline Total & 28 & 100.0 \\
\hline
\end{tabular}

Table 4 reflects on faculty's opinion of the existing services that the CDEL has available. A large amount of the respondents (82\%) were neutral about the services available, denoting no opinion or unsure about it. Only $11 \%$ of respondents were satisfied or very satisfied, and $7 \%$ of respondents were either unsatisfied or very unsatisfied. The large number of respondents that have a neutral opinion or were not sure about their level of satisfaction towards the CDEL office services could be correlated to how $89 \%$ of respondents in table 3 had little or no communication. It can be inferred that the majority of faculty have a neutral opinion of the CDEL because they have not had significant communication and exposure to what CDEL offers.

Research Question \#4: How confident are MacEwan faculty members regarding employment for students after graduation of their program?

Table 5: Degree of Confidence that Students will be Prepared for Employment in their Field of Study after Graduation (Sample mean $=1.89, S D=1.031$ )

\begin{tabular}{llr|r|} 
& Frequency & Percent \\
\hline Valid & 0 & 0.0 \\
& Very Unconfident & 1 & 3.6 \\
\cline { 2 - 3 } & $(1)$ & 11 & 39.3 \\
\hline Unconfident (2) & 12 & 42.9 \\
\hline Neutral (3) & 4 & 14.3 \\
\hline Confident (4) & 28 & 100.0 \\
\hline Very Confident (5) & & \\
\hline
\end{tabular}

Table 5 shows that roughly $57 \%$ of faculty members were either confident or very confident that their students will be prepared for employment after graduating from their program. These are encouraging numbers, with only $4 \%$ of faculty either unconfident or very unconfident, and the remainder are neutral. This univariate analysis shows that at least the majority of faculty members believe that students will have the proper tools necessary to gain employment post-graduation.

Research Question \#5: What is the faculty opinion on the role that they have for preparing students for the labor market after graduation? 


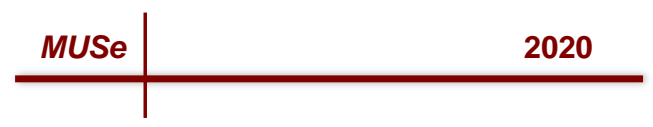

Table 6: Faculty Opinion on their Role of Preparing Students for the Labor Market, Based on a Level of Agreement (sample mean $=2.57, S D=1.2$ )

\begin{tabular}{ll|r|r|} 
& Frequency & \multicolumn{2}{r|}{ Percent } \\
\hline Valid & 0 & 0.0 \\
\cline { 2 - 4 } & Strongly Disagree (1) & 4 & 14.3 \\
\hline Disagree (2) & 8 & 28.6 \\
\cline { 2 - 3 } & & 8 & 28.6 \\
\hline Agree (4) & 8 & 28.6 \\
\hline Strongly Agree (5) & 28 & 100.0 \\
\hline Total & &
\end{tabular}

Table 6 shows that $57 \%$ of all faculty members surveyed agree or strongly agree with the statement that it is part of their job duties to prepare students for employment postgraduation. Only $29 \%$ did not agree nor disagree, and $14 \%$ disagreed with the statement. These findings mirror our initial exploratory research of the importance of fostering student/faculty relationships that the majority believe is also important.

Research Question \#7: What is the faculty opinion regarding the importance of their involvement with the CDEL office to increase student involvement?

Table 7: Faculty Opinion Regarding the Importance of their Involvement with the CDEL Office to Increase Student Involvement ( $1=$ not important, $7=$ very important) (Sample mean $=4.18, S D=1.278$ )

\begin{tabular}{ll|r|r|} 
& & Frequency & Percent \\
\hline Valid & 1 & 3.6 \\
\cline { 2 - 4 } & 2 & 2 & 7.1 \\
\cline { 2 - 4 } 3 & 3 & 10.7 \\
\cline { 2 - 4 } & 4 & 12 & 42.9 \\
\hline 5 & 5 & 17.9 \\
\hline 5 & 5 & 17.9 \\
\hline 6 & 0 & 0.0 \\
\hline 7 & 28 & 100.0 \\
\hline
\end{tabular}

Table 7 shows an objective opinion regarding what faculty believes the importance of their involvement with the CDEL office to overall student involvement. It is important to note that of our sample size, nobody answered that it was very important, however at least $35 \%$ believed it to be somewhat important (denoted by numbers $5 \& 6$ ), whereas around $54 \%$ stated no opinion on the subject (denoted by numbers $3 \& 4$ ). Again, this could be correlated to the results in Table 3 which shows $89 \%$ of faculty have had little or no communication with the CDEL. Only $11 \%$ of respondents felt that it was either unimportant or relatively unimportant (denoted by numbers $1 \& 2$ ).

Research question \#8: Which of the available service would you consider most important for your student's future success? 
Table 8: Descriptive Statistics Regarding Faculty Opinions of the Existing Services that the CDEL Office Provides Students

\begin{tabular}{|c|c|c|c|c|}
\hline \multirow[b]{2}{*}{$\begin{array}{l}\text { Existing Services Available for } \\
\text { Students (by the CDEL office) }\end{array}$} & \multicolumn{3}{|c|}{ Descriptive Statistics } & \multirow[b]{2}{*}{ Std. Deviation } \\
\hline & Minimum & Maximum & Mean & \\
\hline Resume/CV Tips \& Reviews & 3 & 5 & 4.61 & .567 \\
\hline Mock Interview Practice & 2 & 5 & 4.04 & .999 \\
\hline Linkedln Profile Tips and Reviews & 1 & 5 & 2.96 & 1.071 \\
\hline Job Search Help/Strategies & 3 & 5 & 4.21 & .568 \\
\hline Career Discussion Planning & 3 & 5 & 3.96 & .693 \\
\hline Career Placement Advice & 3 & 5 & 4.00 & .720 \\
\hline Graduate School Planning & 1 & 5 & 3.89 & 1.031 \\
\hline $\begin{array}{l}\text { Occupational Related Career } \\
\text { Events }\end{array}$ & 2 & 5 & 4.14 & .756 \\
\hline $\begin{array}{l}\text { Employer/Student Networking } \\
\text { Events }\end{array}$ & 1 & 5 & 4.11 & 1.066 \\
\hline
\end{tabular}

Table 8 shows important insights for what MacEwan faculty members considers important for students. The question was worded as follows: "Which of the available services would you consider most important for your student's future success? (Rating of 1 to $5,1=$ least important, $5=$ most important)". From the data obtained, it seems apparent that there are certain topics that seem to be less important, for instance Linkedln profile tips and reviews had the lowest mean by far at 2.96. On the contrary, other topics such as resume/CV tips and reviews have the highest mean by far at 4.61 , with job search/help strategies coming closely behind with a mean of 4.21 . This data allows us to infer possible strategies that the CDEL office can look into spending more time promoting and dropping or reducing the focus of certain things like Linkedln reviews.

Research Question \#6: What is the faculty opinion on potential services that the CDEL office could implement to increase the usage of their modules for students

Table 9: Descriptive Statistics Regarding Faculty Opinions on What Potential Services the CDEL Office Could Implement that would be Effective for Students 


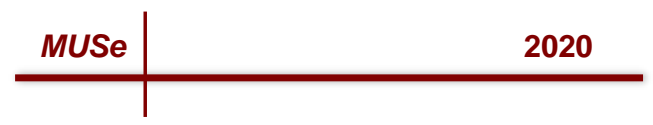

\begin{tabular}{|c|c|c|c|c|}
\hline \multirow[b]{2}{*}{$\begin{array}{l}\text { Potential Changes that the } \\
\text { CDEL office could Implement }\end{array}$} & \multicolumn{3}{|c|}{ Descriptive Statistics } & \multirow[b]{2}{*}{ Std. Deviation } \\
\hline & Minimum & Maximum & Mean & \\
\hline $\begin{array}{l}\text { Online Resources (How-To } \\
\text { Videos) }\end{array}$ & 1 & 5 & 3.88 & 1.107 \\
\hline $\begin{array}{l}\text { Better Hours of Operation } \\
\text { (Weekends/Evenings) }\end{array}$ & 1 & 5 & 2.92 & .935 \\
\hline $\begin{array}{l}\text { Personalized Modules for Each } \\
\text { Field of Study }\end{array}$ & 1 & 5 & 3.73 & .962 \\
\hline Resume Templates & 1 & 5 & 4.19 & .981 \\
\hline Increased Faculty Involvement & 1 & 5 & 3.27 & 1.116 \\
\hline Other & 1 & 5 & 3.00 & 1.342 \\
\hline
\end{tabular}

Table 9 showcases some potential implementations that we as a group considered important for the CDEL to implement. These findings were a result of important recommendations from our in-depth interview answers, stating their concerns as to what they felt the current problems might be regarding student involvement with the CDEL office. As it states, the most important was Resume Templates, with a mean of 4.19 , very close to 5 (which was the highest possible rating). In contrast, certain aspects could be ignored or deleted, for instance better hours of operation on weekends and evenings had a low mean of 2.92. We also added an option for "other" where respondents could state their recommendations for other possibilities not included in the list, and of these only three written responses were added: "to support and promote community service learning/work integrated efforts", "contact with companies, including non-profit organizations and governments", and that they have an existing program of study that focusses on career preparation.

\section{Limitations}

The proposed study of our marketing research project for the Career Development and Experiential Learning Office of MacEwan University is to create awareness and engage/attract students to CDEL's various services provided, through integrating faculty's engagement. However, while conducting our research, our group came across some limitations which could have potentially hindered our success in terms of collecting data. Such limitations include miscommunication among our clients and our group, as we had initially used the wrong email at the beginning of our project which prevented us from getting swift replies. In terms of collecting data for our surveys, our group faced a lot of adversities as some professors, specifically from the psychology department, believed that our group were part of a phishing scheme/scam. Our group's effort to resolve the issue were in vain, as our survey quota was due, and the professors could not do the survey in time. Limited responses were our biggest limitation as the lack of 


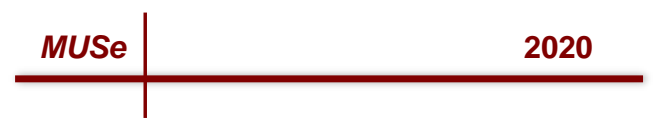

responses prevented us from getting a wide variety of data. This was disappointing as our group together sent out three hundred and sixty-one emails, with only twenty-eight professors and staff replying. This prevented us from reaching our ten percent goal, as we fell short at just around seven percent

\section{Conclusion and Recommendations}

Throughout this project, our group has conducted many of the appropriate studies and action necessary to ensure that we would be well prepared and have the essential knowledge for the current problem of the Career Development and Experiential Learning offices. While doing our initial report, our group studied approximately twenty-five scholarly articles. This provided us with a good foundation as to the strengths and weaknesses of the career services of other facilities being studied. As evident through the studies we've conducted, it is essential to properly understand our client's needs and motives in order to proceed with the main goal of our research, which is to combine the faculty perspective and insight with the needs and advice of the Career Development Office, in order to ensure our target demographic is aware of the services and have a better overall knowledge of the Career Development Office.

With the insight provided through in-depth interviews and surveys conducted, it is evident here are issues that need to be addressed in order to see the success of this module development. Our first recommendation is to have better promotion of the services available at the CDEL offices. The main goal in addressing this problem would be to maximize the awareness of the services towards the designated target market. As evident in our research, the popularity and knowledge of the CDEL office is limited, as not a lot of people are aware of the services CDEL offers. Another recommendation would be to have better communication with professors and staff. As evident in tables two, three, and four, a lack of knowledge from faculty was a major issue we noticed through conducting this research over time. Fixing this issue deals with one of the most important issues we've found in our studies: good word of mouth promotions could see a potential rise in recognition for the CDEL offices. This would be done through mini in-class presentations (and doing these research projects with marketing classes), resulting in raising recognition of the services and key purposes of the Career Development Offices. Finally, our last recommendation is to take suggestions from faculty members to better tailor modules for the needs of each faculty. This provides a better system, as faculty members would be willing to use because it benefits their students specifically. This would allow for a stronger relationship with faculty, which we feel would see an increase in the overall usage of the Career Development and Exponential Learning offices. 


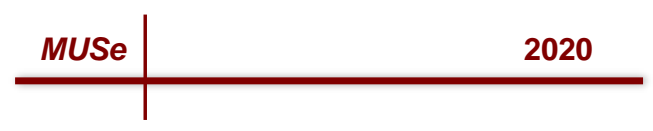

\section{References}

Akos, P., Chao, W., Harbour, S., \& Xia, S. (2016). A Comparison of University Career Services in China and the United States. Journal of Asia Pacific Counseling, 6(1), 51-61.

Retrieved from http://content.ebscohost.com.ezproxy.macewan.ca/ContentServer.asp?EbscoContent=d GJyMNHr7ESeqK84yNfsOLCmr1Cep7ZSs6u4TbGWxWXS\&ContentCustomer=dGJyM PGqtOuyrLVRuePfgeyx43zx1\%2B6B\&T=P\&P=AN\&S=R\&D=a9h\&K=113458683

Bartels, J., \& Ryan, J. (2013). Fear of Failure and Achievement Goals: A Canonical Analysis. Journal Of Instructional Psychology, 40(1-4), 42-29.

Chang, E., Chen, C., Greenberger, E., \& Heckhausen, J. (2013). Striving for Educational and Career Goals During the Transition After High School: What is Beneficial?. Journal of Youth \& Adolescence, 42(9), 1385-1398. Retrieved from http://content.ebscohost.com.ezproxy.macewan.ca/ContentServer.asp?EbscoContent=d GJyMNHr7ESeqK84yNfsOLCmr1Cep7ZSs6\%2B4S7eWxWXS\&ContentCustomer=dGJy MPGqtOuyrLVRuePfgeyx43zx1\%2B6B\&T=P\&P=AN\&S=R\&D=ccm\&K=104211835

Fouad, N.A., Guillen, A., Harris-Hodge, E., Henry, C., Kantamneni, N., Novakovic, A., \& Terry, S. (2006). Need, Awareness, and Use of Career Services for College students. Journal of Career Assessment, 14(4), 407-420. Retrieved from http://journals.sagepub.com.ezproxy.macewan.ca/doi/pdf/10.1177/1069072706288928

Jelena Zikic, M. F. (2010). enriching careers and lives: introducing a positive, holistic, and narrative career counseling method that bridges theory and practice. Journal of Employment Counseling volume 47, issue 4, 180-189. Retrieved from https://library.macewan.ca/library-search/detailedview/ofs/55787018?query=methods+of+job+hunting

Koehly, L.M., \& Shivy, V.A. (2002). Client Perceptions of and Preferences for University-Based Career Services. Journal of Vocational Behaviour, 60(1), 40. Retrieved from https://acels-cdn-com.ezproxy.macewan.ca/S0001879101918111/1-s2.0-S0001879101918111main.pdf? tid=ff7d5362-ff25-11e7-935e$\underline{\text { 00000aab0f01\&acdnat=1516592612 947725f40edf146ba130280aafc150dd }}$

Koć-Januchta, M., Höffler, T., Thoma, G., Prechtl, H., \& Leutner, D. (2017). Visualizers versus verbalizers: Effects of cognitive style on learning with texts and pictures - An eyetracking study. Computers in Human Behavior,68, 170-179. http://dx.doi.org/10.1016/j.chb.2016.11.028

Kollmann, T., Stöckmann, C., \& Kensbock, J. (2017). Fear of failure as a mediator of the relationship between obstacles and nascent entrepreneurial activity-An experimental approach. Journal Of Business Venturing, 32(3), 280-301.

http://dx.doi.org/10.1016/j.jbusvent.2017.02.002 


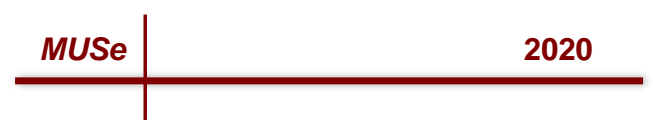

Li, L., \& Pitts, J. P. (2009, June 22). Does It Really Matter? Using Virtual Office Hours to Enhance Student-Faculty Interaction. Journal of Information Systems Education. Retrieved from http://content.ebscohost.com.ezproxy.macewan.ca/ContentServer.asp?EbscoContent=d GJyMNHr7ESeqK84yNfsOLCmr1Cep7NSra\%2B4SrWWxWXS\&ContentCustomer=dGJ yMPGqt0uyrLVRuePfgeyx43zx1\%2B6B\&T=P\&P=AN\&S=R\&D=bth\&K=42008997

LoFrisco, B.M., \& Osborn, D.S. (2012). How Do Career Centers Use Social Networking Sites?. Career Development Quarterly, 60(3), 263-272 Retrieved from http://content.ebscohost.com.ezproxy.macewan.ca/ContentServer.asp?EbscoContent=d GJyMNHr7ESeqK84yNfsOLCmr1Cep7dSraq4SrWWxWXS\&ContentCustomer=dGJyMP Gqt0uyrLVRuePfgeyx43zx1\%2B6B\&T=P\&P=AN\&S=R\&D=afh\&K=82161604

Macdonald, N., \& Hyde, J. (1980). Fear of Success, Need Achievement, and Fear of Failure: A factor analytic study. Sex Roles, 6(5), 695-711. http://dx.doi.org/10.1007/bf00287490

Malhotra, N. K. (2012). Basic marketing research: integration of social media (4th ed.). Boston: Pearson.

Meij, H. V., \& Meij, J. V. (2016). Demonstration-based training (DBT) in the design of a video tutorial for software training. Instructional Science,44(6), 527-542. http://dx.doi.org/10.1007/s11251-016-9394-9

Pascarella, E. T. (1980, December 01). Student-Faculty Informal Contact and College Outcomes. Retrieved January 21, 2018, from http://www.jstor.org/stable/1170295

Pfund, R., Rogan, J. A., Burnham, J. D., Norcross, B. R., \& C., J. (2013, September 1). Is the Professor in? Faculty Presence during Office Hours. College Student Journal. Retrieved from

http://content.ebscohost.com.ezproxy.macewan.ca/ContentServer.asp?EbscoContent=d GJyMNHr7ESeqK84yNfsOLCmr1Cep7JSs664TLSWxWXS\&ContentCustomer=dGJyMP Gat0uyrLVRuePfgeyx43zx1\%2B6B\&T=P\&P=AN\&S=R\&D=s3h\&K=90516451

Piróg, D. (2016). Job search strategies of recent university graduates in Poland: plans and effectiveness. Higher Education (00181560) volume 71, issue 4, 557-573. Retrieved from https://library.macewan.ca/library-search/detailedview/ofs/113929283?query=methods+of+job+hunting

Platt, M., \& Freyd, J. (2015). Betray my trust, shame on me: Shame, dissociation, fear, and betrayal trauma. Psychological Trauma: Theory, Research, Practice, And Policy, 7(4), 398-404. http://dx.doi.org/10.1037/tra0000022

Pursell E. Donald, T. D. (1979). Age and the job-hunting methods of the unemployed. Monthly Labor Review volume 102, issue 1, 68-69. Retrieved from https://library.macewan.ca/library-search/detailedview/edsjsr/edsjsr.41840862?query=methods+of+job+hunting 


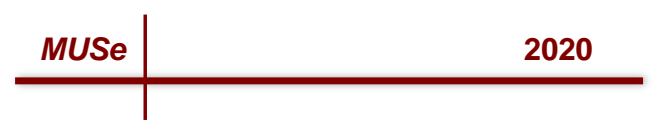

Schwartz, S. E., Kanchewa, S. S., Rhodes, J. E., Cutler, E., \& Cunningham, J. L. (2016). “I didnt know you could just ask:" Empowering underrepresented college-bound students to recruit academic and career mentors. Children and Youth Services Review, 64, 51-59. Retrieved from https://www.sciencedirect.com.ezproxy.macewan.ca/science/article/pii/S0190740916300 640 ? $\mathrm{rdoc}=1 \& \mathrm{fmt}=\mathrm{high} \&$ origin=gateway \& docanchor $=\& \mathrm{md} 5=\mathrm{b} 8429449 \mathrm{ccfc} 9 \mathrm{c} 30159 \mathrm{a}$ $\underline{5 f 9 a e a a 92 f f b}$

Shelton, C. C., Warren, A. E., \& Archambault, L. M. (2016). Exploring the Use of Interactive Digital Storytelling Video: Promoting Student Engagement and Learning in a University Hybrid Course. TechTrends,60(5), 465-474. http://dx.doi.org/10.1007/s11528-016-0082$\underline{z}$

Short, J. C., \& Reeves, T. C. (2009). THE GRAPHIC NOVEL: A "COOL" FORMAT FOR COMMUNICATING TO GENERATION Y. Business Communication Quarterly,42(4), 414-430.

Silvia Ghiselli, L. P. (2015). Determining factors in the job search strategies: A multivariate analysis. Sociologia del Lavoro issue 137, 95-114. Retrieved from https://library.macewan.ca/library-search/detailedview/sih/101661387?query=job+search+strategies

Tsai, K., Chang, H., \& Peng, C. (2016). Refining the linkage between perceived capability and entrepreneurial intention: roles of perceived opportunity, fear of failure, and gender. International Entrepreneurship And Management Journal, 12(4), 1127-1145. http://dx.doi.org/10.1007/s11365-016-0383-x

Volkwein, J. F., King, M. C., \& Terenzini, P. T. (1986). Student-Faculty Relationships and Intellectual Growth among Transfer Students. The Journal of Higher Education, 57(4), 413. Retrieved from: www.jstor.org.ezproxy.macewan.ca/stable/pdf/1980995.pdf?refreqid=excelsior\%3A1040 d647dbda5aaf600e698ff5e1cc8d

Weiner, W. (2016). The INFLUENCE of SOCIAL MEDIA on JOB SEEKERS in the DIGITAL AGE. Career Planning \& Adult Development Journal volume 32, issue 3, 26-31. Retrieved from https://library.macewan.ca/library-search/detailed-view/ehh/119812658

Zhong, L. (2017). Online Teaching Effectiveness with Instructor-made Video Tutorials: A Case of Using Explain Everything. Business Education Innovation Journal, 9(1), 35-42. 


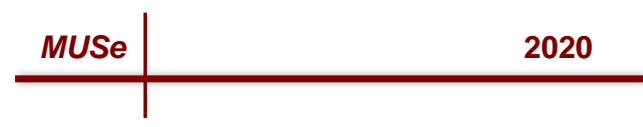

\section{Appendix}

MacEwan University Faculty Involvement/Interest Survey

1. Do you have any knowledge of what The MacEwan Career and Development Office is? $\square$ Yes $\square$ No

2. Where did you first hear about the Career Development Offices?

$\square$ Online $\quad \square$ Through Faculty $\square$ Through Students $\square$ Career Booths $\square$ Through this Survey $\quad \square$ Never Heard of the Office $\quad \square$ Other

3. Are you aware of the "My Career Journey" module that The Career Development Office offers?
$\square$ Yes
$\square$ No

4. Does your program/faculty have a career placement opportunity for students?
$\square$ Yes
$\square$ No
$\square$ Not Directly

5. How interested would you be in devoting course time/percentage to a career skills and development module like the My Career Journey? (Resume/interview advice, job placement information, career mindset positivity, self-awareness/self-confidence etc...)

\begin{tabular}{|ccccc|}
\hline Not Interested & $\begin{array}{c}\text { Not Very } \\
\text { Interested }\end{array}$ & $\begin{array}{c}\text { Neutral (No } \\
\text { Opinion/Unsure) }\end{array}$ & $\begin{array}{c}\text { Somewhat } \\
\text { Interested }\end{array}$ & Very Interested \\
\hline 1 & 2 & 3 & 4 & 5 \\
$\square$ & $\square$ & $\square$ & $\square$ & $\square$ \\
\hline
\end{tabular}

6. Which of the available services would you consider most important for your student's future success? (Rating of 1 to 5, $1=$ least important, $5=$ most important)

\begin{tabular}{|l|l|l|l|l|l|}
\hline Rate the Importance of: & 1 & 2 & 3 & 4 & 5 \\
\hline Resume/CV Tips and Reviews: & & & & & \\
\hline Mock Interview Practice: & & & & & \\
\hline LinkedIn Profile Tips and Reviews: & & & & & \\
\hline Job Search Help: & & & & & \\
\hline Career Discussion Planning: & & & & & \\
\hline Career Placement Advice: & & & & & \\
\hline Career Placement Tests: & & & & & \\
\hline
\end{tabular}

7. What is your level of satisfaction regarding the services that The Career Development Offices offers for students?

\begin{tabular}{|ccccc|}
\hline Unsatisfied & $\begin{array}{c}\text { Somewhat } \\
\text { Unsatisfied }\end{array}$ & $\begin{array}{c}\text { Neutral (No } \\
\text { Opinion/Unsure) }\end{array}$ & $\begin{array}{c}\text { Somewhat } \\
\text { Satisfied }\end{array}$ & Very Satisfied \\
\hline 1 & 2 & 3 & 4 & 5 \\
$\square$ & $\square$ & $\square$ & $\square$ & $\square$ \\
\hline
\end{tabular}

8. How often per year do you have direct contact with The Career Development Office? 
Never

1

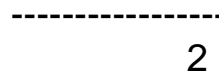

2

3

4

5

-Very Often

6 7

9. How often do students approach you for career advice?

Never

1

2

3

4

5

6

-Very Often

10. Express your degree of confidence that your students are prepared for employment in their field of study after graduation:

\begin{tabular}{|ccccc|}
\hline Least Confident & $\begin{array}{c}\text { Not Very } \\
\text { Confident }\end{array}$ & Neutral & $\begin{array}{c}\text { Somewhat } \\
\text { Confident }\end{array}$ & Very Confident \\
\hline 1 & 2 & 3 & 4 & 5 \\
$\square$ & $\square$ & $\square$ & $\square$ & $\square$ \\
\hline
\end{tabular}

11. To what extent do you agree with the following statement: "As a professor, it is one of your duties to ensure that students are prepared for the job market after graduation":

\begin{tabular}{|ccccc|}
\hline $\begin{array}{c}\text { Strongly } \\
\text { Disagree }\end{array}$ & $\begin{array}{c}\text { Somewhat } \\
\text { Disagree }\end{array}$ & $\begin{array}{c}\text { Neutral (do not } \\
\text { agree/disagree) }\end{array}$ & $\begin{array}{c}\text { Somewhat } \\
\text { Agree }\end{array}$ & Strongly Agree \\
\hline 1 & 2 & 3 & 4 & 5 \\
$\square$ & $\square$ & $\square$ & $\square$ & $\square$ \\
\hline
\end{tabular}

12. Rate the following (potential) services for The Career Development Office that would make student involvement more successful (Rating of 1 to 5, 1 = least important, $5=$ most important)

\begin{tabular}{|l|l|l|l|l|l|}
\hline Rate the Importance of Adding: & 1 & 2 & 3 & 4 & 5 \\
\hline Online Resources (How-To Videos): & & & & & \\
\hline $\begin{array}{l}\text { Better Hours of Operation } \\
\text { (Weekends/Evenings): }\end{array}$ & & & & & \\
\hline $\begin{array}{l}\text { Personalized Modules for Each Field } \\
\text { of Study: }\end{array}$ & & & & & \\
\hline Resume Templates: & & & & & \\
\hline Increased Faculty Involvement: & & & & & \\
\hline
\end{tabular}

13. In your opinion, how important is faculty involvement to the success of the Career Development Office?

Not Important $-3$ $-2$ $-1$

0

14. What faculty are you a part of?

$\square$ Arts \& Sciences $\square$ Fine Arts \& Communications $\square$ Nursing
$\square$ School of Business $\square$ Continuing Education $\square$ Open Studies $\square$ Other


15. What is your current occupational title?

$\square$ Full Professor $\square$ Part Time Professor $\square$ Seasonal Professor $\square$ Other $\square$ Associate Professor $\square$ Assistant Professor $\square$ Sessional Instructor

16. Who shared this questionnaire with you?

$\square$ Wesley Amundson $\square$ Albert Ho Si $\square$ Antonio Makardajh

$\square$ Luke Wurban $\square$ Morgan Bosgoed 